\title{
Perbedaan ukuran mahkota dan servikal gigi kaninus mandibula dan molar pertama maksila melalui pengukuran diagonal pada laki-laki dan perempuan dalam penentuan dimorfisme seksual
}

\author{
Kartika Artha Rini ${ }^{1}$, Masniari Novita ${ }^{1 *}$, Dwi Kartika Apriyono ${ }^{1}$
}

${ }^{1}$ Departemen Biomedik, Fakultas Kedokteran Gigi Universitas Jember, Indonesia

*Korespondensi: masniari@unejac.id

Submisi: 21 Juni 2021; Penerimaan: 26 Februari 2022; Publikasi Online: 28 Februari 2022 DOI: $10.24198 /$ pjdrs.v6i1.34079

\begin{abstract}
ABSTRAK
Pendahuluan: Indonesia merupakan negara yang rentan terhadap bencana alam. Penentuan jenis kelamin menjadi prioritas utama dalam proses identifikasi korban dengan memanfaatkan perbedaan karakteristik gigi antara laki-laki dan perempuan. Metode pengukuran gigi dapat digunakan dalam menentukan jenis kelamin setelah gigi erupsi. Metode pengukuran gigi secara linear dapat dipengaruhi oleh berbagai faktor sehingga kemudian dikembangkan metode pengukuran diagonal. Tujuan penelitian menganalisis perbedaan ukuran mahkota dan servikal gigi kaninus mandibula dan molar pertama maksila melalui pengukuran diagonal pada laki-laki dan perempuan dalam penentuan dimorfisme seksual. Metode: Jenis penelitian crossectional. Sampel terdiri dari 9 model gigi laki-laki dan 36 model gigi perempuan yang diukur lebar mesiobukal-distolingual dan mesiolingual-distobukal mahkota dan servikal gigi kaninus mandibula dan molar pertama maksila dengan kaliper digital. Analisis data menggunakan uji paired t-test dan independent two sample t-test. Hasil: Rerata ukuran gigi kaninus mandibula dan molar pertama maksila pada laki-laki lebih besar dari perempuan. Diameter mahkota dan servikal mesiobukal-distolingual dan mesiolingual-distobukal gigi kaninus mandibula dan molar pertama maksila hampir seluruhnya menunjukkan perbedaan yang signifikan antara laki-laki dan perempuan $(\mathrm{p}<0,05)$, kecuali pada gigi kaninus kiri mandibula dimensi servikal mesiolingual-distobukal $(0,189)$ dan molar pertama kiri maksila dimensi mahkota mesiolingual-distobukal $(0,084)$. Simpulan: Terdapat Perbedaan ukuran mahkota dan servikal mesiobukal-distolingual dan mesiolingual-distobukal gigi kaninus mandibula dan molar pertama maksila menunjukkan perbedaan antara laki-laki dan perempuan, sedangkan gigi kaninus kiri mandibula dimensi servikal mesiolingual-distobukal dan molar pertama kiri maksila dimensi mahkota mesiolingual-distobukal tidak menunjukkan perbedaan. Gigi yang menunjukkan dimorfisme seksual tertinggi yaitu gigi kaninus kanan mandibula dan gigi molar pertama kanan maksila.
\end{abstract}

Kata kunci: dimorfisme seksual; pengukuran diagonal; kaninus mandibula; molar pertama maksila

\section{Differences in the crown and cervical sizes of mandibular canines and maxillary first molars measured with diagonal measurements in males and females in determining sexual dimorphism}

\begin{abstract}
Introduction: Indonesia is a country that is prone to natural disasters. Sex determination is a top priority in the victim identification process by utilising the differences in dental characteristics between males and females. Odontometric measurement can be used in determining sex after tooth eruption. However, odontometric linear can be affected by various factors. As a result, alternative diagonal measurement methods were developed. The study aimed to analyse the differences in the crown and cervical sizes of mandibular canines and maxillary first molars measured with diagonal measurements in males and females in determining sexual dimorphism. Methods: The research was cross-sectional, conducted on nine male dental models and 36 female dental models measured mesiobuccal-distolingual and mesiolingual-distobuccal widths of the crown and cervical canines of the mandibular and maxillary first molars with digital calli-pers. Data analysis using paired t-test and independent two-sample t-test. Results: The mean size of the mandibular canines and maxillary first molars in males were higher than that of females. Almost all mesiobuccal-distolingual and mesiolingual-distobuccal crown and cervical diameters of mandibular canines and maxillary first molars showed significant differences between males and females $(p<0.05)$, except for the mesiolingual-distobuccal left mandibular canine (0.189) and maxillary first molars and maxillary left first molar mesiolingual-distobuccal crown dimension (0.084). Conclusions: There are differences in the mesiobuccal-distolingual and mesiolingual-distobuccal crown and cervical sizes of the mandibular canines and maxillary first molars between males and females while the left mandibular canines mesiolingual-distobuccal cervical dimensions and maxillary left first molars did not show any difference in the mesiolingual-distobuccal dimensions of the crown. The teeth that showed the highest sexual dimorphism were the right mandibular canine and the maxillary right first molar.
\end{abstract}

Keywords: sexual dimoprhism; diagonal measurement; mandibular canine; maxillary first molar 


\section{PENDAHULUAN}

Indonesia merupakan negara yang rentan terhadap bencana alam seperti gempa bumi, letusan gunung berapi, tsunami, dan lain-lain, dikarenakan letaknya yang berada pada pertemuan tiga lempeng utama dunia. ${ }^{1}$ Skala bencana alam yang terjadi biasanya tergolong sebagai bencana besar yang memakan cukup banyak korban dengan kemungkinan kondisi korban yang tidak utuh lagi. Kondisi ini menjadikan korban akan sulit dikenali dan identifikasi korban dengan menggunakan sidik jari akan menyulitkan proses penyelidikan. ${ }^{2}$ Gigi dapat digunakan sebagai bahan identifikasi rekonstruktif, karena ketahanannya terhadap kerusakan post-mortem, stabil secara kimia, dan dapat dipertahankan tanpa batas waktu tertentu setelah kematian sehingga baik untuk penyelidikan forensik. ${ }^{3}$

Penentuan jenis kelamin menjadi prioritas utama dalam proses identifikasi korban oleh ahli forensik dalam berbagai kasus, terutama ketika tidak tersedianya informasi yang berkaitan dengan korban. ${ }^{4}$ Nagare et al, ${ }^{5}$ menyatakan bahwa karakteristik gigi seperti morfologi gigi, ukuran mahkota, dan juga panjang akar dapat dimanfaatkan untuk penentuan jenis kelamin dalam bidang odontologi forensik. Perbedaan karakteristik gigi antara laki-laki dan perempuan terletak pada ketebalan enamel, dentin, dan jaringan pulpa. ${ }^{6}$

Metode pengukuran gigi dapat digunakan dalam menentukan jenis kelamin setelah gigi erupsi. ${ }^{6}$ Sebagian besar penelitian odontologi forensik melakukan pengukuran diameter mesiodistal dan bukolingual mahkota gigi untuk menganalisis dimorfisme seksual. Metode pengukuran ini dapat dipengaruhi oleh berbagai faktor seperti atrisi, aspek keausan interproksimal, abrasi servikal, gigi berjejal, dan adanya kalkulus pada sepertiga servikal, selain itu variasi ini juga akan sulit diukur apabila gigi masih berada dalam soket. Metode pengukuran tersebut kemudian dikembangkan lagi menjadi metode pengukuran gigi secara diagonal atau odontometrik diagonal yang dengan lebih sedikit dipengaruhi oleh faktor-faktor tersebut., ${ }^{3,7}$ Metode pengukuran diagonal diukur melalui jarak terjauh sudut mesiobukal-distolingual dan mesiolingual-distobukal pada mahkota dan servikal gigi. ${ }^{7}$ Keuntungan utama dari pengukuran diameter diagonal yakni, bahwa sumbu diagonal tidak termasuk titik kontak mahkota oleh karena itu pengukuran ini tidak dipengaruhi oleh atrisi hingga derajat atrisi tersebut menjadi cukup besar. Kekurangan dari pengukuran diagonal ini ialah diperlukan kehati-hatian dalam melakukan pengukuran, karena garis oklusal mahkota bukan persegi panjang biasa dan tingkat sudut-sudut yang membulat bervariasi. ${ }^{3}$

Studi mengenai penentuan jenis kelamin melalui pengukuran diagonal menyebutkan bahwa gigi kaninus mandibula menunjukkan seksual dimorfisme tertinggi dan dimorfisme seksual mahkota gigi kaninus lebih besar pada laki-laki dibandingkan perempuan., ${ }^{3,8}$ Gigi kaninus sangat berkontribusi dalam identifikasi jenis kelamin melalui seksual dimorfisme. ${ }^{9}$ Gigi kaninus memiliki kelebihan tertentu, yaitu gigi ini merupakan gigi yang paling jarang diekstraksi dan tidak terpengaruh oleh penyakit periodontal, selain itu gigi ini juga memiliki peluang lebih tinggi untuk selamat dari trauma parah bahkan dalam bencana badai dan udara maupun kondisi ekstrim lainnya. ${ }^{3,10}$

Banyak penelitian yang sudah membuktikan bahwa gigi kaninus mandibula menunjukkan dimorfisme seksual tertinggi yang kemudian diikuti gigi molar pertama maksila. Molar pertama maksila termasuk gigi permanen yang erupsi di awal yakni pada usia 6-7 tahun. Estimasi jenis kelamin pada kasus anakanak melalui skeletal akan sulit dilakukan, sehingga pengukuran gigi yang erupsi pada usia dini sangat bermanfaat dalam penentuan jenis kelamin. ${ }^{11,3}$ Gigi molar maksila memiliki desain yang berbeda dengan gigi yang lain. Gigi molar maksila adalah gigi yang terbesar dan terkuat berdasarkan ukuran dan perlekatannya pada rahang. ${ }^{12}$ Tujuan penelitian menganalisis perbedaan ukuran mahkota dan servikal gigi kaninus mandibula dan molar pertama maksila melalui pengukuran diagonal pada lakilaki dan perempuan dalam penentuan dimorfisme seksual.

\section{METODE}

Jenis penelitian iobservasional analitik dengan pendekatan cross sectional. Pelaksanaan penelitian pada bulan Desember 2019-Februari 2020 dengan populasi penelitian adalah mahasiswa laki-laki dan perempuan Fakultas Kedokteran Gigi Universitas Jember angkatan 2016-2019 sebanyak 576 mahasiswa, dengan jumlah mahasiswa laki-laki sebanyak 111 dan mahasiswa perempuan sebanyak 465. 
Penentuan jumlah sampel minimal dihitung menggunakan rumus sampel cross-sectional dan didapatkan jumlah sampel minimal sebesar 45 mahasiswa Fakultas Kedokteran Gigi Universitas Jember angkatan 2016-2019. Penentuan jumlah sampel laki-laki dan perempuan ditentukan secara proporsional berdasarkan prosentase pada populasi tersebut sehingga didapatkan jumlah sampel sebesar 36 mahasiswa perempuan dan 9 mahasiswa laki-laki (Gambar 1). Pengambilan sampel pada penelitian ini dilakukan dengan teknik purposive sampling, dengan kriteria inklusi yakni; Subjek penelitian merupakan mahasiswa Fakultas Kedokteran Gigi Universitas Jember angkatan 2016-2019 yang bersedia dan tidak alergi bahan cetak alginate, serta tidak dalam perawatan ortodonti.

Subjek penelitian dipilih dan dilakukan pemeriksaan oleh dokter gigi klinik Oral Diagnosis

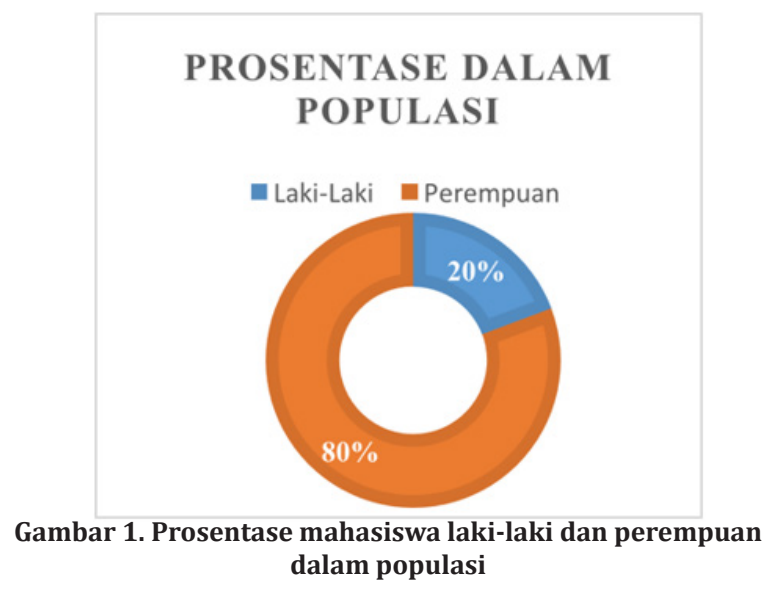

RSGM Universitas Jember. Sampel yang terpilih kemudian dilakukan pencetakan gigi pada klinik Prosthodonsia RSGM Universitas Jember dengan menggunakan bahan cetak alginate. Hasil cetakan tersebut selanjutnya diisi dengan bahan pengisi gips tipe III/Gips kuning pada gigi yang akan dilakukan pengamatan dan gips tipe II/Gips biru pada seluruh daerah cetakan.

Model gigi hasil cetakan kemudian diukur lebar mesiobukal-distolingual dan mesiolingualdistobukal pada mahkota dan servikal gigi kaninus mandibula dan molar pertama maksila dengan menggunakan kaliper digital sebanyak dua kali oleh dua orang pengamat dalam waktu yang berbeda. Data yang telah diperoleh kemudian dilakukan uji beda Paired T-Test untuk mengevaluasi variasi intraobserver pada pengukuran diagonal mahkota dan servikal gigi kaninus mandibula dan molar pertama maksila, kemudian dilakukan uji Independent Two Sample T-Test untuk menguji apakah lakilaki memiliki perbedaan yang signifikan terhadap perempuan. Penelitian ini sudah mendapatkan persetujuan dari Komisi Etik Penelitian Kesehatan (KEPK) Fakultas Kedokteran Gigi Universitas Jember (No. 750/UN25.8/KEPK/DL/2019).

\section{HASIL}

Hasil uji Independent Two Sample T-Test pada tabel 1 menunjukkan diameter mahkota mesiobukaldistolingual pada gigi kaninus mandibula serta molar pertama maksila seluruhnya menunjukkan perbedaan yang signifikan antara laki-laki dan perempuan $(\mathrm{p}<0,05)$. Tabel 2 yang diukur melalui diameter mahkota mesiolingual-distobukal gigi kaninus mandibula dan gigi molar pertama kanan maksila menunjukkan adanya perbedaan yang signifikan antara laki-laki dan perempuan, sedangkan pada gigi molar pertama kiri maksila (gigi 26) menunjukkan signifikansi sebesar 0,084, sehingga dapat dinyatakan bahwa tidak terdapat perbedaan yang signifikan antara laki-laki dan perempuan $(p>0,05)$.

Diameter servikal mesiobukal-distolingual (Tabel 3) pada gigi kaninus mandibula kanan dan kiri serta gigi molar pertama maksila kanan dan kiri menunjukkan nilai $\mathrm{p}<0,05$ sehingga dapat dikatakan terdapat perbedaan yang signifikan antara laki-laki dan perempuan dalam dimensi ini. Pengukuran diameter servikal mesiolingual-distobukal (Tabel 4) menunjukkan terdapat perbedaan yang signifikan antara laki-laki dan perempuan pada seluruh gigi, kecuali pada gigi kaninus kiri mandibula (gigi 33) dengan nilai signifikansi lebih dari 0,05 yaitu sebesar 0,189. Gambar 2 menunjukkan prosentase dimorfisme seksual melalui pengukuran diagonal pada seluruh dimensi dari gigi kaninus mandibula dan molar pertama maksila. Mahkota mesiobukal-distolingual menunjukkan dimorfisme seksual tertinggi, kemudian diikuti oleh mahkota mesiolingual-distobukal, servikal mesiobukaldistolingual, servikal mesiolingual-distobukal. Gigi yang paling menunjukkan dimorfisme seksual pada pengukuran diagonal diantara gigi kaninus mandibula kanan dan kiri serta molar pertama maksila kanan dan kiri yaitu gigi kaninus kanan mandibula dan molar pertama kanan maksila. Gigigigi yang lain menunjukkan adanya dimorfisme 
Tabel 1. Hasil uji independent two sample t-test mahkota mesiobukal-distolingual

\begin{tabular}{|c|c|c|c|c|c|c|}
\hline \multirow[b]{2}{*}{ Gigi } & \multicolumn{2}{|c|}{ Laki-Laki } & \multicolumn{2}{|c|}{ Perempuan } & \multirow{2}{*}{$\begin{array}{c}\text { \% Dimorfisme } \\
\text { Seksual }^{\mathrm{a}}\end{array}$} & \multirow{2}{*}{$\begin{array}{c}\text { Sig. } \\
\text { (2-tailed) }\end{array}$} \\
\hline & $\begin{array}{c}\text { Rerata } \\
(\mathrm{mm})\end{array}$ & S.D. & $\begin{array}{c}\text { Rerata } \\
(\mathrm{mm})\end{array}$ & S.D. & & \\
\hline Gigi 43 & 7,10 & 0,48 & 6,36 & 0,35 & 11,61 & 0,001 \\
\hline Gigi 33 & 7,06 & 0,56 & 6,39 & 0,42 & 10,38 & 0,001 \\
\hline Gigi 16 & 12,98 & 0,63 & 12,15 & 0,44 & 6,85 & 0,001 \\
\hline Gigi 26 & 13,00 & 0,55 & 12,29 & 0,52 & 5,78 & 0,001 \\
\hline
\end{tabular}

Tabel 2. Uji Hasil independent two sample t-test mahkota mesiolingual-distobukal

\begin{tabular}{|c|c|c|c|c|c|c|}
\hline \multirow[b]{2}{*}{ Gigi } & \multicolumn{2}{|c|}{ Laki-Laki } & \multicolumn{2}{|c|}{ Perempuan } & \multirow{2}{*}{$\begin{array}{c}\text { \%Dimorfisme } \\
\text { Seksual }^{\mathrm{a}}\end{array}$} & \multirow{2}{*}{$\begin{array}{c}\text { Sig. } \\
\text { (2-tailed) }\end{array}$} \\
\hline & $\begin{array}{c}\text { Rerata } \\
(\mathrm{mm})\end{array}$ & S.D. & $\begin{array}{c}\text { Rerata } \\
\text { (mm) }\end{array}$ & S.D. & & \\
\hline Gigi 43 & 6,72 & 0,34 & 6,17 & 0,34 & 8,89 & 0,001 \\
\hline Gigi 33 & 6,79 & 0,34 & 6,16 & 0,40 & 10,17 & 0,001 \\
\hline Gigi 16 & 11,76 & 0,79 & 10,86 & 0,49 & 8,25 & 0,009 \\
\hline Gigi 26 & 11,48 & 0,92 & 10,87 & 0,57 & 5,68 & 0,084 \\
\hline
\end{tabular}

Tabel 3. Hasil uji independent two sample t-test servikal mesiobukal-distolingual

\begin{tabular}{|c|c|c|c|c|c|c|}
\hline \multirow{2}{*}{ Gigi } & \multirow{2}{*}{$\begin{array}{c}\text { Laki-Laki } \\
\text { Rerata (mm) }\end{array}$} & \multicolumn{3}{|c|}{ Perempuan } & \multirow[t]{2}{*}{$\begin{array}{c}\text { \%Dimorfisme } \\
\text { Seksual }^{\mathrm{a}}\end{array}$} & \multirow[t]{2}{*}{ Sig. (2-tailed) } \\
\hline & & S.D. & Rerata (mm) & S.D. & & \\
\hline Gigi 43 & 7,50 & 0,80 & 6,90 & 0,49 & 8,75 & 0,006 \\
\hline Gigi 33 & 7,46 & 0,66 & 6,98 & 0,52 & 6,94 & 0,022 \\
\hline Gigi 16 & 13,20 & 0,58 & 12,35 & 0,50 & 6,92 & 0,001 \\
\hline Gigi 26 & 13,30 & 0,53 & 12,36 & 0,53 & 7,61 & 0,001 \\
\hline
\end{tabular}

Tabel 4. Hasil uji independent two sample t-test mahkota mesiolingual-distobukal

\begin{tabular}{|c|c|c|c|c|c|c|}
\hline \multirow[b]{2}{*}{ Gigi } & \multicolumn{2}{|c|}{ Laki-Laki } & \multicolumn{2}{|c|}{ Perempuan } & \multirow{2}{*}{$\begin{array}{c}\text { \%Dimorfisme } \\
\text { Seksual }^{\mathrm{a}}\end{array}$} & \multirow{2}{*}{$\begin{array}{c}\text { Sig. } \\
\text { (2-tailed) }\end{array}$} \\
\hline & $\begin{array}{l}\text { Rerata } \\
\text { (mm) }\end{array}$ & S.D. & $\begin{array}{l}\text { Rerata } \\
\text { (mm) }\end{array}$ & S.D. & & \\
\hline Gigi 43 & 7,05 & 0,58 & 6,53 & 0,49 & 8,04 & 0,008 \\
\hline Gigi 33 & 6,84 & 0,61 & 6,59 & 0,49 & 3,86 & 0,189 \\
\hline Gigi 16 & 12,13 & 0,72 & 11,34 & 0,55 & 6,96 & 0,001 \\
\hline Gigi 26 & 12,04 & 0,71 & 11,34 & 0,51 & 6,19 & 0,001 \\
\hline
\end{tabular}

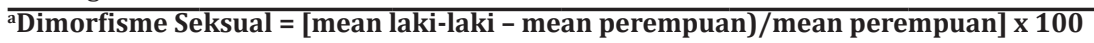

seksual, tetapi tidak menunjukkan adanya perbedaan yang signifikan antara laki-laki dan perempuan, seperti pada gigi kaninus kiri mandibula diameter servikal mesiolingual-distobukal (Tabel 4) dan molar pertama kiri maksila diameter mahkota mesiolingual-distobukal (Tabel 2). Laki-laki memiliki rerata ukuran gigi yang lebih besar daripada perempuan baik pada gigi kaninus mandibula maupun molar pertama maksila dan dari total 16 pengukuran, menunjukkan adanya perbedaan yang signifikan $(\mathrm{p}<0,05)$ antara laki-laki dan perempuan pada sejumlah 14 pengukuran dan 2 pengukuran yang menunjukkan tidak ada perbedaan yang signifikan antara laki-laki dan perempuan.

\section{PEMBAHASAN}

Penelitian ini memperoleh hasil bahwa terdapat perbedaan pada lebar mesiobukal-distolingual dan mesiolingual-distobukal pada mahkota dan servikal gigi kaninus mandibula serta molar pertama maksila antara laki-laki dan perempuan. Hasil penelitian ini menunjukkan rerata ukuran gigi laki-laki lebih besar daripada perempuan pada seluruh dimensinya (mesiobukal-distolingual dan mesiolingualdistobukal pada mahkota dan servikal gigi). Hal ini sesuai dengan penelitian-penelitian odontometrik diagonal sebelumnya dan sama halnya dengan hasil penelitian- penelitian odontometrik linear yang 
juga menunjukkan ukuran gigi laki-laki lebih besar daripada perempuan pada diameter mesio-distal dan buko-lingual. ${ }^{13,14,15}$ Penelitian oleh Alvesalo,et al di Finlandia menyatakan bahwa kromosom seks berperan penting terhadap pertumbuhan gigi dan studi tersebut mengonfirmasi bahwa kromosom $\mathrm{X}$ dan $\mathrm{Y}$ memiliki efek yang berbeda terhadap pertumbuhan gigi. ${ }^{16,17}$ Kromosom Y meningkatkan pertumbuhan enamel dan dentin, sedangkan kromosom X tampaknya hanya mempengaruhi enamel, sehingga hal ini mempengaruhi pada perbedaan ukuran gigi antara laki-laki dan perempuan, dikarenakan secara genetik laki-laki adalah individu dengan kode genetik XY, sedangkan perempuan adalah XX. ${ }^{16,17}$

Faktor hormonal juga mempengaruhi perbedaan ukuran gigi geligi. Ribeiro et $a^{18}$ menyatakan bahwa kadar testosteron juga berpengaruh terhadap variasi ukuran gigi geligi pada laki-laki dan perempuan.. Hal ini dikarenakan testosteron terikat oleh reseptor androgen di sitoplasma sel. Kompleks ini kemudian dapat memasuki nukleus, di mana ia berikatan dengan DNA dan mempengaruhi transkripsi. ${ }^{18}$ Efek testosteron dapat berlanjut ketika level tinggi tidak lagi ada. Studi tersebut menyatakan bahwa kromosom seks da hormon intrauterine level mampu mempengaruhi ukuran gigi laki-laki dan perempuan. ${ }^{18}$

Beberapa penelitian menyatakan bahwa gigi kaninus mandibula merupakan gigi yang menunjukkan dimorfisme seksual tertinggi, yang selanjutnya diikuti oleh gigi molar pertama maksila. Penelitian yang dilakukan pada ras kaukasoid menunjukkan adanya dimorfisme seksual. ${ }^{19}$ Gigi kaninus kanan mandibula dalam penelitian ini menunjukkan dimorfisme seksual tertinggi, yang kemudian diikuti oleh gigi molar pertama kanan maksila. Gigi kaninus kiri mandibula dan molar pertama kiri maksila juga menunjukkan adanya dimorfisme seksual, hanya saja tidak terdapat perbedaan yang signifikan antara laki-laki dan perempuan pada gigi kaninus kiri mandibula dimensi servikal mesiolingual-distobukal dan gigi molar pertama kiri maksila dimensi mahkota mesiolingualdistobukal. Pengukuran diagonal gigi molar pada populasi Afrika Amerika oleh Peckmann et al ${ }^{20}$ yang diukur pada kerangka manusia menunjukkan terdapat perbedaan yang signifikan antara laki-laki dan perempuan, dengan gigi yang menunjukkan dimorfisme seksual tertinggi yaitu pada ketiga gigi molar maksila. Hal tersebut berbeda dengan hasil penelitian Zorba et al ${ }^{7}$ yang menyatakan bahwa tidak terdapat perbedaan yang signifikan antara laki-laki dan perempuan pada gigi molar pertama maksila dimensi servikal mesiobukal-distolingual.

Pengukuran diagonal yang dilakukan pada penelitian ini menunjukkan rerata ukuran gigi molar pertama maksila yang lebih besar apabila dibandingkan dengan rerata ukuran molar pada populasi Davangere menurut penelitian Mujib et al, ${ }^{3}$. Beberapa faktor yang dapat berkontribusi terhadap perbedaan ini salah satunya adalah pengaruh lingkungan karena terdapat variasi sumber daya makanan pada populasi yang berbeda. ${ }^{14}$ Zorba et al menyatakan bahwa gigi dapat berukuran lebih besar dalam populasi yang mengandalkan makanan nabati lebih dari daging. ${ }^{7}$ Perbedaan ukuran tersebut juga dapat disebabkan akan adanya variasi ras atau keturunan. Setiap ras memiliki morfologi tertentu yang mempengaruhi perbedaan ukuran gigi. ${ }^{21}$

Gigi dapat memberikan bukti tentang sifat dan tingkat keragaman antara populasi manusia dan variasi ukuran mahkota gigi. Data mengenai dimensi gigi dari populasi yang berbeda di seluruh dunia menunjukkan bahwa populasi Eurasia barat cenderung memiliki gigi terkecil, dengan penduduk asli Australia, Melanesia, Mikronesia, Sub-Sahara, dan penduduk asli Amerika cenderung memiliki gigi besar.

Populasi Asia Timur dan Asia Tenggara tergolong dalam ukuran gigi yang sedang di antara kelompok tersebut. ${ }^{22}$ Variasi tersebut dapat dijadikan sebagai indikator pada masing-masing populasi dan faktanya bahwa dimorfisme seksual adalah fenomena spesifik populasi. Perbedaan pola dimorfisme seksual antara populasi adalah akibat dari faktor genetik dan latar belakang lingkungan yang berbeda-beda. Oleh sebab itu pola dimorfisme dari penelitian ini juga akan berbeda dengan penelitian yang lain, seperti pada penelitian Zorba et $a T^{7}$ yang dilakukan pada populasi Yunani yang disebakan adanya beberapa faktor tersebut. ${ }^{18,7}$

Penentuan jenis kelamin yang sering dilakukan adalah dengan cara pengukuran gigi melalui metode linear yaitu dihitung pada diametermesio-distal dan buko-lingual. Pengukuran tersebut menghasilkan data yang akurat apabila pengukuran gigi memungkinkan untuk dilakukan. Beberapa kondisi seperti rotasi gigi, gigi berjejal, anomali ortodontik, atrisi oklusal, tumpatan mesio-oklusal, disto-oklusal, 
mesio-okluso-distal dapat menghalangi proses pengukuran linear tersebut. Metode pengukuran diagonal yang lebih sedikit dipengaruhi oleh kondisi tersebut dapat dijadikan alternatif pilihan dalam menentukan jenis kelamin, karena pengukuran diagonal tidak melibatkan titik kontak mahkota dan tidak dipengaruhi oleh atrisi proksimal hingga derajat atrisi tersebut menjadi cukup besar. ${ }^{14}$

Metode pengukuran gigi linear menunjukkan derajat dimorfisme seksual yang tinggi, namun metode pengukuran diagonal menunjukkan derajat dimorfisme seksual yang lebih tinggi dibandingkan metode pengukuran linear. ${ }^{23}$ Sebuah studi juga menyatakan bahwa, apabila pengukuran linear pada gigi tertentu memiliki tingkat akurasi yang tinggi, maka pengukuran diagonal pada gigi tersebut juga memiliki tingkat akurasi yang tinggi. Dengan demikian metode pengukuran diagonal dapat dianggap sebagai metode yang lebih dapat diandalkan untuk penentuan jenis kelamin dibandingkan metode linear. ${ }^{3,24}$

Saran yang dapat diberikan yaitu perlu dilakukan penelitian dengan jumlah sampel yang lebih besar. Selain itu perlu dilakukan penelitian lebih lanjut mengenai pengukuran diameter diagonal gigi pada selain gigi kaninus mandibula dan molar pertama maksila dan perlu dilakukan penelitian untuk mengukur berbagai aspek ukuran dan bentuk gigi yang tidak terlalu dipengaruhi oleh keausan.

\section{SIMPULAN}

Terdapat Perbedaan ukuran mahkota dan servikal mesiobukal-distolingual dan mesiolingual distobukal gigi kaninus mandibula dan molar pertama maksila menunjukkan perbedaan antara laki-laki dan perempuan, sedangkan gigi kaninus kiri mandibula dimensi servikal mesiolingual-distobukal dan molar pertama kiri maksila dimensi mahkota mesiolingual-distobukal tidak menunjukkan perbedaan. Gigi yang menunjukkan dimorfisme seksual tertinggi yaitu gigi kaninus kanan mandibula dan gigi molar pertama kanan maksila.

\section{DAFTAR PUSTAKA}

1. Sahelangi P, Novita M. Role of dentists in Indonesian disaster victim identification operations: religious and cultural aspects. J Forensic Odontostomatol. 2012; 30 Suppl 1:60-
71.

2. Larasati AW, Irianto MG, Bustomi EC. Peran pemeriksaan odontologi forensik dalam mengidentifikasi identitas korban bencana masal. Majority. 2018; 7(3): 228-33.

3. Mujib AB, Tarigoppula RK, Kulkarni PG, Bs A. Gender determination using diagonal measurements of maxillary molar and canine teeth in davangere population. J Clin Diagn Res. 2014; 8(11): ZC141-ZC144. DOI: $10.7860 /$ JCDR/2014/9944.5218

4. Ramakrishnan K, Sharma S, Sreeja C, Pratima DB, Aesha I, Vijayabanu B. Sex determination in forensic odontology: A review. J Pharm Bioallied Sci. 2015; 7(Suppl 2): S398-S402. DOI: 10.4103/0975-7406.163469

5. Nagare SP, Chaudhari RS, Birangane RS, Parkarwar PC. Sex determination in forensic identification, a review. J Forensic Dent Sci. 2018; 10(2): 61-6. DOI: 10.4103/jfo.jfds 5517.

6. Dumpala RK, Guttikonda VR, Madala J, Kanth S. Sex determination using diagonal measurement of teeth in a tribal and an urban population: a comparative study. Int J Cont Med Res. 2014;1(2):27-33.

7. Zorba E, Moraitis K, Eliopoulos C, Spiliopoulou C. Sex determination in modern Greeks using diagonal measurements of molar teeth. Forensic Sci Int. 2012; 217(1-3): 19-26. DOI: 10.1016/j. forsciint.2011.09.020.

8. De Angelis D, Gibelli D, Gaudio D, Cipriani Noce F, Guercini N, Varvara G, Sguazza E, Sforza C, Cattaneo C. Sexual dimorphism of canine volume: a pilot study. Leg Med (Tokyo). 2015; 17(3):1636. DOI: 10.1016/j.legalmed.2014.12.006.

9. Bakkannavar SM, Manjunath S, Nayak VC, Kumar GP. Canine index - A tool for sex determination. Egypt J Forensic Sciences. 2015; 5(4): 157-161. DOI: $10.1016 / j . e j f s .2014 .08 .008$

10. Kalistu SN, Doggalli N. Gender determination by forensic odontologist: A review of various methods. IOSR J Dent Medl Sci. 2016; 15(11): 7885. DOI: $10.9790 / 0853-1511017885$

11. Lathifah N, Yuniastuti M, Djohan W. Studi mengenai ukuran mesiodistal dan bukolingual mahkota gigi molar satu rahang atas untuk menentukan jenis kelamin. [Skripsi]. Jakarta: Fakultas Kedokteran Gigi Universitas Indonesia; 2013. hal.1-13

12. Nelson SJ. Wheeler's Dental Anatomy, Physiology 
and Occlusion. 10 ${ }^{\text {th }}$ Ed. Las Vegas: Elsevier. 2015. pp.392

13. Nonitha $S$, Nagaraj $T$, Dave $S$, Sharma $N$, Sherashiya P, Hermavathy S. Sexual dimorphism in Iranian population using diagonal distances on the facial and occlusal surfaces of mandibular frst molar. J Adv Clin Res Insights. 2016; 3(1): 1822. DOI: $10.15713 /$ ins.jcri.97

14. Shivani P, Rutuja KP, Kezia JE. Odontometric sex assessment using diagonal measurements of maxillary first premolar and maxillary first molar teeth in Nagpur population. Int J Sci and Res Public. 2018; 8(11): 525-34. DOI: 10.29322/ IJSRP.8.11.2018.p8356

15. Litha, Girish HC, Murgod S, Savita JK. Gender determination by odontometric method. J Forensic Dent Sci. 2017; 9(1): 44. DOI: 10.4103/ jfo.jfds 9615

16. Townsend G, Bockmann M, Hughes T, Brook A. Genetic, environmental and epigenetic influences on variation in human tooth number, size and shape. Odontology. 2012; 100 (1): 1-9. DOI: $10.1007 / \mathrm{s} 10266-011-0052-\mathrm{Z}$

17. Balwant R dan Kaur J. Evidence-Based Forensic Dentistry. Berlin: Springer Science \& Business Media. 2013. DOI: 10.1007/978-3-642-28994119

18. Ribeiro DC, Brook AH, Hughes TE, Sampson WJ, Townsend GC. Intrauterine hormone effects on tooth dimensions. J Dent Res. 2013; 92(5): 42531. DOI: $10.1177 / 0022034513484934$.
19. Fernandes TM, Sathler R, Natalício GL, Henriques JF, Pinzan A. Comparison of mesiodistal tooth widths in Caucasian, African and Japanese individuals with Brazilian ancestry and normal occlusion. Dental Press J Orthod. 2013 ; 18(3): 130-5. DOI: 10.1590/s217694512013000300021.

20. Peckmann TR, Meek S, Dilkie N, Mussett M. Sex estimation using diagonal diameter measurements of molar teeth in African American populations. J Forensic Legal Med. 2015; 36: 7080. DOI:10.1016/j.jflm.2015.09.001

21. Scheid RC dan Weiss G. Woelfel's Dental Anatomy. $8^{\text {th }}$ Ed. Philadelphia: Lippincot Williams \& Wilkins, a Wolters Kluwer. 2012. 504 p.

22. Deepak V, Goryawala SN, Redd Y, Chhabra RJ, Nandaprasad, Shah NK. Assessment of Ethnicity in Indian Population using Tooth Crown Metric Dental Traits. J Int Oral Health. 2015; 7(9): 8387.

23. Manchanda AS, Narang RS, Kahlon SS, Singh B. Diagonal tooth measurements in sex assessment: A study on North Indian population. J Forensic Dent Sci. 2015; 7(2): 126-31. DOI: 10.4103/0975-1475.146371

24. Lomi M, Jonathan Daniel. M. Accuracy of using diagonal measurements of maxillary canine, first premolar and first molar teeth in sex determination in a Pondicherry Cohort. Int Dent J Stud Res. 2021;9(3): 140-145. DOI: 10.18231/j. idjsr.2021.026 